IRA-International Journal of Management \& Social Sciences

ISSN 2455-2267; Vol.05, Issue 02 (2016)

Pg. no. 245-255

Institute of Research Advances

http://research-advances.org/index.php/RAJMSS

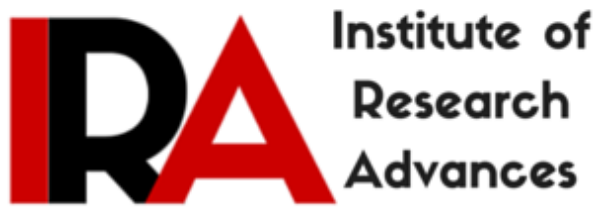

\title{
A Comparative Study on Corporate Governance Standards and Practices with Special Reference to Indian Banking Industry
}

\author{
Dr. Syed Abdul Hameed \\ Assistant Professor, \\ Department of Corporate Secretaryship, \\ The New College, Chennai, India.
}

Type of Review: Peer Reviewed.

DOI: http://dx.doi.org/10.21013/jmss.v5.n2.p4

\section{How to cite this paper:}

Hameed, S. (2016). A Comparative Study on Corporate Governance Standards and Practices with Special Reference to Indian Banking Industry. IRA-International Journal of Management \& Social Sciences (ISSN 2455-2267), 5(2), 245-255. doi:http://dx.doi.org/10.21013/jmss.v5.n2.p4

(C) Institute of Research Advances

\section{(cc) EY-NC}

This work is licensed under a Creative Commons Attribution-Non Commercial 4.0 International License subject to proper citation to the publication source of the work.

Disclaimer: The scholarly papers as reviewed and published by the Institute of Research Advances (IRA) are the views and opinions of their respective authors and are not the views or opinions of the IRA. The IRA disclaims of any harm or loss caused due to the published content to any party. 


ABSTRACT
The vital constituent of an economy are Banks. The significance of banking sector is highlighted by
the fact that it is an internationally regulated industry and the banks are under the purview of
financial regulators of the country. It is of pivotal significance that the banks have robust corporate
governance. A new clause 49 was introduced by SEBI in the listing agreement before a decade
mentioning the principles of corporate governance to be followed by the listed companies. In the
following years SEBI revised clause 49 several times after incorporating the recommendation of
various committees. After taking into account the various trends and factors related to corporate
Governance the topic entitled. "A comparative study of corporate standards and practices with
special reference to Indian Banking Industry" has been drafted to assess the structure and processes
of corporate governance followed by select banks in India and their effectiveness in the content of
substance and quality of reporting of corporate governance activities in the annual reports. The study
also looks in to the state of compliance of key governance benchmarks in the select banks and offers
suggestions to accomplish better governance standards.

\section{INTRODUCTION}

Nothing is permanent in their world except change. The globalization, liberalization and advancement in technology has led to a paradigm shift in the conduct of doing business. The term governance involves the use of political authority and exercise of control in relative to the management of its resources for attaining the worthy objectives of the organization. With drastic change in the business scenario and emergence of new provisions by world bodies, the concept of corporate governance is fast gathering steam. It gives emphasis on apt management and control structure of a corporate undertaking, power relations between various stake holders. Corporate governance is gaining prominence in various national and international forums. The organization for economic co-operation and development has mentioned a set of corporate governance standards and guidelines to assist governments in their endeavors to assess and improvise overall frame work for corporate governance in their countries and to efficiently manage all those groups who have a role in the formulation of good corporate governance and practices.

Corporate governance takes into account the methodology in which the companies and is activities are governed by their boards of directors and how it affect banks from the point of view of banking industry contemporary practice papers issued by the basel committee underscore the requirement for banks to evolve plans for their executive and to fix responsibility for executing those plans.

\section{Statement of the problem}

In the listing agreement in the year 2000, SEBI introduced anew clause 49 mentioning the principles of corporate governance to be followed by the listed companies. In continuation SEBI took on board the suggestions and recommendations of several committees and updated and restructured it several times among the series of amendments made to clause 49 of the listing agreement SEBI issued yet another circular on 15th September 2014 amending clause 49 aligning it with the companies Act, 2013. This circular came into effect from October, 2014. Thus the present study entitled.

"A COMPARATIVE STUDY ON CORPORATE GOVERNANCE STANDARDS AND PRACTICES WITH SPECIAL REFERENCE TO INDIAN BANKING INDUSTRY" has been taken upto assess the extent of compliance with key governance aspects in the selected banks in terms of substance and quality of reporting of governance standards and activities in annual reports for the year 2014-15. 


\section{REVIEW OF LITERATURE}

Corporate governance importance arises in modern corporations due to the separation of management and ownership control in the organizations. The interests of shareholders are conflicting with the interests of managers. The principal agent problem is reflected in the management and direction related problems due to the differential interests of firm's stakeholders. There is not a single definition of corporate governance rather it might be viewed from different angles. Berle and Means (1932) and the even earlier Smith (1776).Zingales (1998) defines corporate governance as "allocation of ownership, capital structure, managerial incentive schemes, takeovers, board of directors, pressure from institutional investors, product market competition, labour market competition, organisational structure, etc., can all be thought of as institutions that affect the process through which quasi-rents are distributed (p. 4)". Garvey and Swan (1994) assert that "governance determines how the firm's top decision makers (executives) actually administer such contracts (p. 139)". Shleifer and Vishny (1997) define corporate governance as "the ways in which suppliers of finance to corporations assure themselves of getting a return on their investment (p.737)". OECD in 1999 defined corporate governance as "Corporate governance is the system by which business corporations are directed and controlled. The corporate governance structure specifies the distribution of rights and responsibilities among different participants in the corporation, such as, the board, managers, shareholders and other stakeholders, and spells out the rules and procedures for making decisions on corporate affairs. By doing this, it also provides the structure through which the company objectives are set, and the means of attaining those objectives and monitoring performance." Oman (2001) defined corporate governance as a term refers to the private and public institutions that include laws, regulations and the business practices which governs the relationship between the corporate managers and the stakeholders.The Ministry of Finance, Singapore (CORPORATE GOVERNANCE 2001) defines corporate governance as "the processes and structure by which the business and affairs of the company are directed and managed, in order to enhance long term shareholder value through enhancing corporate performance and accountability, whilst taking into account the interests of other stakeholders. Good corporate governance therefore embodies both enterprise (performance) and accountability (conformance)." (Fin, 2004, pp 13-14). La Porta, Silanes and Shliefer (2000, 2002) view corporate governance as a set of mechanisms through which outside investors (shareholders) protect themselves from inside investors (managers). The Organization for Economic Cooperation and Development provides another perspective by stating that "corporate governance is the system by which business corporations are directed and controlled. The corporate governance structure specifies the distribution of rights and responsibilities among different participants inthe corporation, such as the Board, managers, shareholders and other stakeholders, and spells out the rules and procedure for making decisions on corporate affairs. By doing this, it also provides the structures through which the company objectives are set, and the means of attaining those objectives and monitoring performance.

\section{Objectives of the study}

To pursue, analyse and study the Research problem the following objectives are formulated

1. To study the Genesis and concept of corporate governance with a special focus and emphasis to banks.

2. To make a comparative study between corporate governance practices adopted by SBI and ICICI.

3. To asses and evaluate the corporate governance standards and practices based on the parameters adopted by SBI and ICICI Bank. 


\section{Genesis and concept corporate governance}

Corporate governance is an age old concept which provides for a frame work for guidelines and transparent relationship between board of directors, shareholders and other stakeholders. Corporate Governance is gaining prominence in recent times because of mis-management of corporate undertakings and disillusionmentamong the stakeholders corporate governance is now a phenomenon for enhancing efficiency and eventually capital. from the banking perspective, corporate governance involves the way in which the functioning and affairs of individual institutions are governed by their boards of directors and senior management and how they impact the functioning of banks. It considers the interest of all the stakeholders. It aligns corporate activities and behaviour with the expectation that banks will operate in a sincere and efficient manner and in compliance with the pertinent and applicable laws and provisions and to protect the interests of depositors.

The new rational practice papers issued by the basel committee highlight the need for banks to develop methodologies for their functioning and prescribe responsibility for implementing these methodologies. Effective corporate governance is critical to the proper functioning of the banking sector and the economy as a whole while there is no single approach to good corporate governance, the committee's revised principles provide a frame work within which banks and supervisors should operate to achieve robust and transparent risk management and decision making and, in doing so, promote public confidence and uphold the safety, security and vibrancy of the banking system.

\section{RESEARCH METHODOLOGY}

This study is an empirical study which is based an both primary and secondary data. The primary data needed was collected from bank officials. The secondary data was collected from the annual reports, corporate governance reports, reports of RBI, Journals and websites of banking sector. The sample for this study comprises of two formidable banks. One is State Bank of India which happens to be the biggest public sector bank and the other one is ICICI Bank the largest Private Sector bank.

These banks are listed on the BSE sensex and NSE Nifty. These banks have been opted for study on the basis that their shares have a profound effect on the stock market fluctuations of the country. The are the major players in the Indian Banking Industry in India with major market share in this sector. This study utilised the annual reports of these banks for the year 2014-15. 


\section{Shareholding pattern of SBI and ICICI Bank}

TABLE 1

Table exhibiting the shareholding pattern of SBI and ICICI Bank for the year 2014-15

\begin{tabular}{|c|r|r|}
\hline \multicolumn{1}{|c|}{ Categories } & SBI (\%) & $\begin{array}{c}\text { ICICI Bank Ltd. } \\
\text { (\%) }\end{array}$ \\
\hline Total number of shares & $746,57,30,320$ & $579,72,44,645$ \\
\hline $\begin{array}{l}\text { A) Shareholding of Promoter Reserve Bank of } \\
\text { India }\end{array}$ & $58.59 \%$ & \\
\hline $\begin{array}{l}\text { B) Shareholding of non-promoters } \\
\text { i. NRI, FII, GDR }\end{array}$ & $5.83 \%$ & $18.34 \%$ \\
\hline ii. Dentsche Bank Trust company & & $29.05 \%$ \\
\hline iii. Financial institutions & $21.66 \%$ & $14.19 \%$ \\
\hline iv. Mutual funds / Govt companies / UTI & $5.07 \%$ & $0.37 \%$ \\
\hline v. Domestic companies trusts & $2.33 \%$ & 100.00 \\
\hline Non-Institutions a) Bodies corporate & & \\
\hline b) Other including Resident individuals & 6.52 & 29.05 \\
\hline
\end{tabular}

Source: Compiled from Annual Reports of SBI and ICICI Bank Ltd.

Shareholding pattern of SBI and ICICI Bank for the year 2014-15 is shown in Table-I. The observations made are as follows.

The majority of share of SBI are held by Reserve Bank of India as it is a Government owned bank and it is patronised by the non-Residents including Foreign Institutional Investors. But ICICI Bank being a private sector bank major shares are by non-resident, Foreign institutional investors and Dentsche Bank Trust company.

Senior management team is in charge of management and control of SBI and ICICI Bank under the supervision of the board. 
TABLE - 2

Table exhibiting the board structure, strength and size of SBI and ICIC Bank Ltd for the year 2014-15.

\begin{tabular}{|c|c|c|}
\hline Particulars & SBI & $\begin{array}{c}\text { ICICI Bank } \\
\text { Ltd. }\end{array}$ \\
\hline 1. Total number of Directors & 14 & 17 \\
\hline \multicolumn{3}{|l|}{ Number of Executive Directors (Whole time) } \\
\hline Chairman & 1 & 1 \\
\hline Managing Directors & 2 & 1 (also CEO) \\
\hline Others (Joint MD, Deputy MD) & - & 4 \\
\hline \multicolumn{3}{|l|}{ Number of non-Executive Directors (NEDs) } \\
\hline Independent Directors (Elected by shareholder) & 4 & 10 \\
\hline \multicolumn{3}{|l|}{ Nominees from } \\
\hline Central Government & 3 & 1 \\
\hline GOI Officials & 1 & - \\
\hline RBI & 1 & \\
\hline Representatives (Workers and non-workmen-staff) & 2 & \\
\hline \multicolumn{3}{|l|}{ 2. Total number and percentage of } \\
\hline Executive Directors (EDs) & $3(21 \%)$ & \\
\hline Non-Executive Directors (NEDs) & $11(79 \%)$ & $11(65 \%)$ \\
\hline Independence Directors (ID) & $4(29 \%)$ & $10(59 \%)$ \\
\hline
\end{tabular}

Source : Annual Reports of SBI and ICICI Bank Ltd.

The Table two exhibits the board structure, strength and size of SBI and ICICI Bank Ltd. The total number of directors is more in the case of ICICI Bank in comparison to that of SBI. The revised provision of clause 49 of the listing agreement has been adequately met by SBI in comparison to that of ICICI Bank Limited. 


\section{TABLE 3}

Table showing directors attendance in board meetings of SBI and ICIC Bank Ltd. during 20142015

\begin{tabular}{|c|c|c|c|c|c|}
\hline \multirow{2}{*}{$\begin{array}{c}\text { Number of } \\
\text { Board } \\
\text { Meetings }\end{array}$} & \multicolumn{2}{|c|}{ SBI } & \multirow{2}{*}{$\begin{array}{c}\text { Number of } \\
\text { Board } \\
\text { Meetings }\end{array}$} & \multicolumn{2}{|c|}{ ICICI Bank } \\
\hline & NEDs & $\begin{array}{l}\text { EDs } \\
(+C)\end{array}$ & & IDs $(+C)$ & $\begin{array}{c}\text { Whole time } \\
\text { Directors (MDs) }\end{array}$ \\
\hline 0 & 1 & - & 0 & - & - \\
\hline 1 & - & - & 1 & 1 & - \\
\hline 2 & - & - & 2 & 2 & - \\
\hline 3 & 1 & - & 3 & 4 & - \\
\hline 4 & 1 & - & 4 & 1 & - \\
\hline 5 & - & - & 5 & 2 & - \\
\hline 6 & 1 & - & 6 & $2(+C)$ & $5(+\mathrm{MD})$ \\
\hline 7 & 2 & 1 & & & \\
\hline 8 & 1 & - & & & \\
\hline 9 & 1 & $1(\mathrm{c})$ & & & \\
\hline 10 & 3 & 1 & & & \\
\hline Total & 11 & 3 & Total & 12 & 5 \\
\hline Last AGM & 8 & 3 & Last AGM & 10 & 5 \\
\hline
\end{tabular}

Source; Annual Reports 2014-15 Results computed

$+\mathrm{C} / \mathrm{C}$ including chairman / chairman

+ MD including Managing Director : AGM - Annual General Meeting

NED - Non executive Directors

The above table exhibits the directors attendance in board meetings of SBI and ICICI Bank Ltd in the year 2014-15. The following are the observations made

1. The frequency at which the board at which SBI met is higher than ICICI Bank Ltd.

2. The statistics of directors attendance in the ICICI Bank's Board is marginally better than SBI.

3. Although the provisions of revised clause 49 of the listing agreement and section 285 of the companies act regarding minimum number of board meetings to be held in a year have been complied with by both the banks, the permissible gap between two board meeting is three months, but in one case ICICI Bank has marginally exceeded this permissible limit. 


\section{TABLE NO.4}

Table exhibiting the criteria for assessment of Governance standards for the year 2014-15.

\begin{tabular}{|c|c|c|}
\hline $\begin{array}{l}\text { Sl. } \\
\text { No. }\end{array}$ & Governance Parameters & $\begin{array}{c}\text { Point Score } \\
\text { Assigned }\end{array}$ \\
\hline 1. & Statement of Bank's philosophy on code of governance & 2. \\
\hline 2. & Structure and strength of the board & 2 \\
\hline 3. & Chairman and CEO duality: & 4 (maximum) \\
\hline a. & Promoter Executive Chairman-cum-MD/CEO & \\
\hline $\mathrm{b}$. & Non-promoter Executive Chairman cum MD/CEO & \\
\hline c. & Promoter non-Executive Chairman & \\
\hline d. & Non-promoter non-Executive Chairman & \\
\hline e. & Non-Executive Independent Chairman & \\
\hline 4. & Disclosure of tenure and age limit of directors & 3 \\
\hline 5. & Disclosure of & \\
\hline a. & Definition of Independent Director & 1 \\
\hline $\mathrm{b}$. & Definition of Financial Expert & 1 \\
\hline c. & Selection criteria of board of directors including IDS & 1 \\
\hline 6. & $\begin{array}{l}\text { Post-board meeting follow up system and compliance of board } \\
\text { procedure }\end{array}$ & 2 \\
\hline 7. & Appointment of Lead Independent Director & 2 \\
\hline 8. & Disclosure of other provisions as to the Board and Committees & 1 \\
\hline 9. & Disclosure of & \\
\hline a. & Remuneration of policy & 1 \\
\hline b. & Affirmation of compliance & 1 \\
\hline 10. & Code of conduct & \\
\hline a. & Information on code of conduct & 1 \\
\hline b. & Affirmation of compliance & 1 \\
\hline 11. & Board Committees and its functioning & \\
\hline A. & Executive Committee of Central Board & $\begin{array}{c}(25) \\
1\end{array}$ \\
\hline B. & Audit Committee & 5 \\
\hline C. & Board Governance \&\& Remuneration / Compensation Committee & 2 \\
\hline D. & Credit Committee & 2 \\
\hline E. & Fraud Monitoring Committee & 3 \\
\hline F. & Risk Management Committee & 3 \\
\hline G. & Share Transfer \& Shareholders / Investors Grievance Committee & 2 \\
\hline $\mathrm{H}$. & Asset Liability Management Committee & 3 \\
\hline I. & Customer Service Committee & 2 \\
\hline $\mathrm{J}$. & Technology Committee & 2 \\
\hline 12. & Disclosure and Transparency & \\
\hline a. & Significant related party transactions having potential conflicts with & 2 \\
\hline
\end{tabular}




\begin{tabular}{|c|c|c|}
\hline & the interest of the bank & \\
\hline b. & $\begin{array}{l}\text { Non-compliance related to capital market matters during last three } \\
\text { years. }\end{array}$ & 2 \\
\hline c. & Accounting treatment & 2 \\
\hline \multirow[t]{3}{*}{$\mathrm{d}}$. & Board disclosure - Risk Management & \\
\hline & i. Information to the Board on risk management & 2 \\
\hline & ii. Publishing of risk management report & 1 \\
\hline e. & Management Discussion and Analysis & 2 \\
\hline \multirow[t]{5}{*}{ f. } & Shareholder's information & \\
\hline & $\begin{array}{l}\text { i. Appointment of new director / reappointment of retiring } \\
\text { directors }\end{array}$ & 1 \\
\hline & ii. Quarterly results \& presentation & 1 \\
\hline & iii. Share transfers & 1 \\
\hline & iv. Directors Responsibility Statement & 1 \\
\hline g. & Shareholders rights & 2 \\
\hline h. & Audit qualifications & 2 \\
\hline i. & Training of board members & 2 \\
\hline $\mathrm{j}$. & Evaluation of non-executive directors & 2 \\
\hline $\mathrm{k}$. & Whistle blower policy & 2 \\
\hline 13. & General Body Meetings & \\
\hline a. & Location \& time of general meetings held in last three years & 1 \\
\hline b. & Details of special resolutions passed in the last three AGMs & 1 \\
\hline c. & $\begin{array}{l}\text { Details of resolutions passed last year through postal ballot } \\
\text { including the name of conducting official and voting procedure }\end{array}$ & 1 \\
\hline 14. & Means of communication \& general shareholder information & 2 \\
\hline 15. & CEO / CFO certification & 2 \\
\hline 16. & $\begin{array}{l}\text { Compliance of Corporate Governance and Auditor's } \\
\text { Certificate }\end{array}$ & $\begin{array}{c}10 \\
\text { (maximum) }\end{array}$ \\
\hline a. & Clean certificate from auditors & \\
\hline b. & Qualified certificate from auditors & \\
\hline 17. & Disclosure of stakeholders interests & $(10)$ \\
\hline a. & Human Resources Development initiatives (HRD) & 3 \\
\hline b. & Corporate Social Responsibility (CSR) & 3 \\
\hline c. & Industrial Relations (R) & 2 \\
\hline $\mathrm{d}$. & Disclosure of policies on EHS, HRD, CSR \& IR & 2 \\
\hline & Total & 100 \\
\hline
\end{tabular}


The above table depicts a set of criteria which has been evolved based on the point value system to know how for these banks adhere to governance standards, along with their due weightage according to their significance. The key governance parameters and the criteria for evaluation of governance standards have been opted for a 100 point scale.

TABLE NO.5

Table showing the grading an a five-point scale

\begin{tabular}{|c|c|}
\hline Score Range & Rank \\
\hline $90-100$ & Excellent \\
\hline $81-89$ & Very Good \\
\hline $66-80$ & Good \\
\hline $50-65$ & Satisfactory \\
\hline Below 50 & Poor \\
\hline
\end{tabular}

The basis of grading have been mentioned in the above Table. After determining the total score based an established parameters, both banks and industry have been evaluated an a five-point scale. Accordingly each of these two banks has been awarded points an key parameters.

TABLE NO.6

Table showing cumulative scores secured by SBI and ICICI Bank Ltd.

\begin{tabular}{|c|c|c|}
\hline SBI's Score & ICICI Banks score & Indian Banking Average Score \\
\hline 78 & 80 & 79 \\
\hline
\end{tabular}

Table - 6 presents the resorts that the governance standards and practices in both the banks are very good. SBI got 82 points and ICICI Bank obtained 84 points. It also brought to the fore the country's banking industry represented by there two major listed banks has an overall score of 83 points this showing good performance in maintaining the standards and accomplishing the quality of governance standards.

\section{RESEARCH FINDINGS}

1. The vision and mission of SBI mentions that it is committed to the best practices in the domain of corporate governance and through which it can maintain a high level of business ethics and to earn the good will of all stake holders. The Bank's commitment to corporate governance is obvious through its governance objectives such as transparency, integrity and accountability.

2. ICICI Bank Ltd has incorporated a conventions of best practices in corporate governance. The corporate governance structure is based on an efficient independent board, whistle blower polity and tab in is den trading. 
3. Both SBI and ICICI Bank adhered to the principles of corporate governance by having different persons for positions of CEO and chairman.

4. The positions like independent director, financial expert and their selection criteria have not been not been defined by both the banks.

5. The Annual Reports of both the banks exhibit that they have not divulged any information about past-board meeting follow-up about the decisions taken.

6. In line with SEBI regulations ICICI Bank disclosed the remunerations policy in its corporate governance report. A detailed breakup of remuneration was given.

7. The adoption of code of conduct and the information related to it have been furnished in the annual reports of both the banks.

8. Adequate information Recording Human Resource Development and Corporate Social Responsibility has not been given in Annual Report.

\section{CONCLUSION}

It has come to the fore from the research study undertaken to make a comparative research analysis on the corporate governance standards and practices in Indian Banking Industry that the Corporate governance standards, practices and quality of disclosures by the Indian Banking Industry is good and endeavour must be made to scale greater heights to make headway in the global scenario. The banks must be sensitive to the needs, wants and aspirations of customers and other stakeholders in a rational manner and corporate governance must synchronize with it to develop and prosper in an international scenario.

\section{REFERENCES}

Souvenir-Second ICSI National Award for Excellence in Corporate Governance, December 2002 Chartered, August 2003.

Vision - The Journal of Business Perspective

S.Sadri and S.Jayashree (2006) : Business Ethics and Corporate Governance (Towers Organisational Excellence).

Alison Maitland (1999). "The value of virtue in A Transport World," Business Standard, Mumbai.

http://en.wikipedia.org/wiki/corporate-governance

http://www.tradechakra.com/business-culture-india.html

http://business.gov.in/corporate_governance/intex.php

Dr.Nishabhavsar, H.L., College of Commerce, Ahmedabad, Gujarat, India.

www.statebankofindia.com

www.icicibank.com

www.rbi.org.in 